International Journal of Agriculture, Environment and Bioresearch

Vol. 4, No. 05; 2019

ISSN: $2456-8643$

\title{
ADOPTION OF SUSTAINABLE PRACTICES AMONG FOOD AND BEVERAGE SMES IN PENINSULAR MALAYSIA
}

\author{
UmiNadirah Mat Yusuf, NolilaMohd Nawi, NittyHirawaty Kamarulzaman, and Norsida Man \\ Department of Agribusiness and Bioresource Economics, Faculty of Agriculture, Universiti Putra Malaysia ,43400 \\ UPM Serdang
}

http://doi.org/10.35410/IJAEB.2019.4436

\begin{abstract}
Small and Medium-sized enterprises manufacturing sector contributed significantly to Malaysian economy. Specifically, food and beverages SMEs industry play an important part in fulfilling the increasing food demands in Malaysia. However, there is a rising concern on the environmental degradation caused by the aforementioned sector and sustainable practices have been identified as an approach to minimize the effect of manufacturing activities towards environmental degradation. Thus, the aim of this research is to examine the adoption of sustainable manufacturing practices among food and beverages SME's in Peninsular Malaysia. This study was based on a quantitative approach and the primary data were collected using structured questionnaire via face to face interview with 375 manufacturers. Data collected were analysed using descriptive and chi square analysis. Majority of the respondents agreed that improving brand image, reducing overall business costs and increasing profit as benefits gained by the SMEs from adopting sustainable practices. Chi-square analysis revealed that region of business profile is significant in the adoption of sustainable practices among food and beverages SMEs in Peninsular Malaysia. The findings provide further evidence that the adoption of sustainable practices in their manufacturing activities not only provide economic benefits but more importantly, minimize the effect towards environmental degradation.
\end{abstract}

Keywords: food and beverages SMEs, sustainable practices, chi-square analysis.

\section{INTRODUCTION}

According to Department of Statistics Malaysia, the actual gross domestic product (GDP) of SME shave continuously outperformed the overall economy with an average annual growth rate of 6.6\% compared with 5.2\% achieved by the overall GDP in the 2011-2017. This has led to an increase in SMEs' contribution to overall GDP from 32.2\% in 2010 to $37.1 \%$ in 2017.Small and medium-sized companies accounted for $37.1 \%$ of GDP, $66.0 \%$ of employment and $17.3 \%$ of exports in 2017 compared with 2016. Currently, Malaysia has a total number of 907,065 enterprises that are active and still in operation. Out of the total, micro, small, and medium enterprises formed as a category and are involved in the various sectors such as service (89.2\%), manufacturing (5.3\%), construction $(4.3 \%)$, agricultural (1.1\%) and quarrying $(0.1 \%)$ [1].SMEs contributed significantly in terms of economic development to the country especially in the production of food products that meet the specifications of the international standard. The manufacturing industry contributed $21.5 \%$ to the total GDP of SMEs in 2017 [1] and within the 
industry, food, drinks and tobacco accounted for $21.8 \%$ of the total value added of SMEs. This demonstrates that the food and beverage industry contributed significantly to the manufacturing sector of SMEs.Indeed, SMEs have created more employment opportunities, increased income and changed the life course of populations and formed the vital construction blocks for bigger companies. Accordingly, SMEs have increasingly positioned itself in a working business system globally. In fact, Malaysia's SMEs are becoming a main development catalyst to achieve a strong revenue and inclusive country by 2020 .

Human population is increasing every day, and this has led to the increase in the productivity of food products. Food is the most essential necessity to sustain human life.Consequently, manufacturers are compelled to increase their production scale to meet the growing demand for food products.The Malaysian food industry has developed remarkably in the past two decades and is vital to the Malaysian economy and development as it contributes greatly to the Malaysian trade. The food production sector accounts for about $10 \%$ of the manufacturing industry in Malaysia and [2] revealed that Malaysia produced approximately RM14.2 billion food products in 2013 with shipments to over 200 nations worldwide. In 2017, processed food has contributed RM21.1 billion with shipments to more than 200 countries, while the value of imported processed food is RM20.7 billion [3]. The food commodities sub-sector is projected to expand at an average rate of $7.6 \%$ per year owing to the enhanced efficiency of production as declared by the Ministry of Agriculture and Agri-Based Industry (MOA). Therefore, food processing industry in the country will be encouraged and boostedto emerge as crucial element of the agro-based industry. In the Third Industrial Malaysian Plan 2006-2020 (IMP3), the Ministry of International Trade and Industry (MITI) granted a total of RM24.6 billion to aid the food and beverage production sector.

Micro, small, medium or large and in any industry that includes manufacturing, agriculture or even services utilize basic resources such as land, water and energy[4]. Therefore, it is not an exception for small SMEs to excuse and disregard their effects on social and/or ecological issues. Out-dated technologies, lack of efficiency in raw material management and lack of awareness with legislation, as well as pollution control facilities are still used by most of the SMEs these days [5]- [7] added it is inevitable that the edible food waste is disposed to landfill despite the growing realization and interest towards minimizing the food waste initiatives. Food waste anaerobic digestion in landfill generates methane that is twenty-one times more powerful than carbon dioxide. According to [8],food packaging is strongly associated with food production sector that requires comprehensive systematic waste management given the increasing amount of landfill produced, coupled with the limitation faced by the cities' waste handling management. Sample surveys in United States estimated that processed food travels more than 1,300 miles, while fresh produce travels lengthy distances. Consequently, an immense amount of greenhouse gas (GHG) produced along the way is the outcome of the use of massive quantities of fossil, particularly by imported food. Furthermore, approximately $11 \%$ of the worldwide food system's GHG emissions are due to food transportation. Food miles and $\mathrm{CO}_{2}$ emissions are currently subject to intense argument especially among the economies of developed world as they pertain to climate change and sustainability of food production and distribution system. Business activities of exports and imports for food producing will come along at a high price; in distinction with a number of environmental activists who presume the global sourcing as detrimental to environment, harm regional economies, and hinder several 
aspects of communities such as induced noise and accidental rate. Consequently, food processing and production are accused of being one of the main contributors to disrupting the sustainability of the ecosystem

[9] added that land, air, and water contamination from food's manufacturing processes, and rapid increase of greenhouse gas (GHG) emission from within the decomposition of organic waste and the food supply chain are the effects from the food production and consumption. Besides, [10] revealed that GHG released from food production and consumption are predicted to increase further in light of the exponential growth in human population. In addition, increase in the complexity of worldwide food supply chains is the result from the increase of consumers' demand on seasonal and more varied food products [11]. A study on food, greenhouse gas emission and the changing climate by [12]disputed that worldwide environmental degradation was caused by food production and consumption. According to [13],the estimated collective communal of small and medium-sized companies (SMEs) manufacturing operations toward the ecosystem is noteworthy and could exceed the overall environmental impact of large companies.Despite the fact that many prior researches have focused on the latter. In short, the consideration of SMEs industries in the environmental management and social literatures is still open for debate.

Research by the Malaysian Agricultural Research and Development Institute(MARDI) revealed an alarming statistic that 15,000 tons of food is wasted every day. Food waste in Malaysia has hit a critical point, as statistics from the Solid Waste Management and Public Cleansing Corporation (SWCorp) reported that $55 \%$ of solid waste disposed in landfills consists of food. Malaysians allegedly have at least 3,000 metric tons of food per day that is still eligible for consumption, with the quantity increasing during the festive season [14]. In addition, food represented between $31 \%$ and $45 \%$ of the 36,000 tons of waste produced annually by Malaysians. The treatment procedure for all food waste and the transportation to treatment plants require fuel. The process of producing, packaging and transporting food waste involves built-in energy expenses equivalent to nearly 15 million tons of carbon dioxide annually [15].Sustainable practices are therefore, required and seen as a primary source of improved company performance by many manufacturing firms in many countries across the globe, including the Asia-Pacific region, United Kingdom and the United States [16] -[17].

Implementing sustainable methods in manufacturing activities promote the development of manufacturing item that use minimum amount of material or energy resources and minimize environmental impacts. In addition, the exercise also promotes sustainable procedures and maintains substance or energy reserves of manufacturing technologies and supply chains. Furthermore, government, policy makers and consumer are pressuring the food and beverages manufacturers to engage in sustainable practices. This concern has necessitated the need to implement sustainable manufacturing practices which is aimed at reducing the negative impact of manufacturing sector,especially in thedaily operation of food and beverages industries on the environment. While sustainable practices are practiced and extensively researched in developed countries, its advocacy and implementation in developing countries is still in its infancy [18].Therefore, this study seeks at providing insights into the adoption ofsustainable practices in developing countries, particularly in Malaysia emphasizing on food and beverages SMEs.

\section{LITERATURE REVIEW}


Vol. 4, No. 05; 2019

ISSN: $2456-8643$

\subsection{Sustainable Practices}

Usually a constrained definition of manufacturing is used to describe the physical material shift or method of turning input materials into products. Sustainable manufacturing is defined by the US Department of Commerce (2001) as the 'creation of manufactured products that minimize negative environmental impacts, conserve energy and natural resources, are safe for employees, communities and consumers and are economically sound'. According to the [19],the capacity of business of larger firms can be defined by evaluating their economic efficiency and then utilized the information acquired to create decisions on improving techniques that can contribute to greater adoption of sustainable manufacturing practices. [20]viewed sustainable environmental practices as techniques, policies and the procedures taken by a firm with specific aim of monitoring and controlling the effects of the firm's operations on the natural environment. Sustainable manufacturing encompasses the control of value chain to generate end products and outcomes along the supply chain where changes can be made. Hence, reducing the product's packaging or using recyclable packaging may occur at every stage of the supply chain. Plantbased and recycled contents are alternatives to petroleum-based materials that can be incorporated into products to become environmentally friendly [21].Research from [21]revealed that scholars, industry, governments, and trade associations adopted different definitions of sustainable manufacturing. Over time, the definition of sustainable manufacturing has evolved as more studies are conducted to develop better understanding on concepts of sustainable manufacturing. There are two independent elements yet related in sustainable manufacturing whichinclude the production that uses minimum material or energy resources and minimize the environmental impacts along their life cycle stage. There are four main concepts of sustainable practices, namely Total Quality Management (TQM), Corporate Social Responsibility (CSR), lean and green practices. These include operations in reducing waste, while simultaneously emphasizing on ethical commitment [21].

Study by [22]added that lean manufacturing, which is synonymous with the Toyota Production System (TPS), began in Japan after World War II. Eliminating waste which results in greater efficiencies, is the idea behind TPS and "lean". Waste involves overproduction, human capital, inventory, movement, correction, over-processing and storage. Lean manufacturing strategies enhance business efficiency by improving manufacturing productivity by decreasing set-up times and work in process inventory that improve throughput times [23]. Moreover, [24]indicatedthe outcomes of lean practices adopted by Portuguese food and beverage firms as increase in production flexibility and reduce in lead times. Research conducted by [25]on green manufacturing demonstrated that the word "green" is frequently used to denote environmentally safe. The Green Party first developed this ideology in Australia in the early 1970s. Specifically, it seeks to eradicate or minimize waste that has a negative impact on the atmosphere. "Green" production often referred to as sustainable production. Such disposal products are hazardous to the environment and natural resources. In addition to the end product, green production also involves the awareness of the life cycle of a product. This implies that elements and equipment produced and used throughout the supply chain are toxic.Furthermore, theemissions of products used at every stage throughout the supply chain isintentional when an item is being produced.

[21]reportedthat the commonly quoted "Triple Bottom Line" or simply "people, planet, profits" are included in many businesses as attempts on being sustainable. Study on the implementation of TQM in the food industry in Germany shows positive effects on the 
achievement of the business through the adoption of methods [26].The TQM of W. Edwards Deming is also essential for sustainable production. It enables a business to produce more sustainably by being more effective and using fewer natural resources; however, in the name of sustainability, most firms will not risk their product's worth [26].The concept of corporate social responsibility is beyond the organizations' quality production and it is the bottom line of a company to instil morality and ethics to employees, suppliers, customers, and local community. The phrase "corporate social responsibility" has been used by business since the 1960s [21].Besides, [27]agreed that 'corporate ' duties and how a business handles its staff and their communities are part of the social responsibility. [28]added that social accountability relies on integrating procedures and strategies that are aware of social effects in day-to-day business activities. Among others that are included in social responsibility practices are those related to fundamental needs and quality of life, volunteers, integration into social networks and gender equity, labour practices and human rights [29], training employees in sustainability, sustainable education, and outreach [25]. [30]in their study on the concept of sustainable manufacturing concluded that all of the principles,namely lean, green, TQM, and CSR are employed in today's sustainable manufacturing. Fundamentally, sustainable production reduces energy, water and waste.It also increases awareness on the impacts of manufacturing processes among workers and local communities. Overall, we define sustainable production as using less power and resources to generate a product that is equally effective and of the same quality as a replacement product.

A sustainable manufacturing devise ways and strategies to decrease resource consumption through improved efficiency in manufacturing processes, eliminate unnecessary resource use, and decrease the amount of waste and emissions produced through manufacturing activities [21]. There are four primary operations in sustainable manufacturing that include reduce in energy use, water, emissions from manufacturing procedures, and physical waste. These operations parallel the process and product efficiency enhancement that cross all areas of a company's production, transportation and distribution activities. The creation of wildlife habitats, installation of renewable energy production in crops, transformation of waste into income flows and the improvement of societies at the location of installations are among the other projects included in sustainable production methods [21].SMEs play important roles in shaping the food industry's social and environmental impacts [31] - [33]. Therefore, sustainable practice among SMEs may support the environmental, social and economic development especially in low-income countries. In fact, [18]identified sustainable manufacturing as one of the key environmental initiatives. Generally, the implementation of sustainable manufacturing can contribute to better environmental performance.

\subsection{Business Profile}

[34] asserted that organizational factors, for example, size of the organization are one of the factors influencing the adoption of lean manufacturing in SMEs manufacturing activities. Firms are struggling to adoptthe sustainable manufacturing practices which are limited by their "smallness"on the resources [35] - [37].Meanwhile, [38]concluded that the SMEs are not readily involve in good environmental management practices due to their inadequate management capability and skills and also lack of resources that hinder their engagement in other management areas, such as human resource management, strategic planning and training [39] - [40]. SMEs in urban, rural, regional and remote areas are owned and operated by both men and women of all 
ages with varying educational and ethnic backgrounds. The heterogeneity of SMEs nature further complicates the communication as a discrete group and efforts must be coordinated to provide target and specific technical assistance [5], [41].The communication issue is exacerbated by the lack of capacity for environmental training [42] and the fact that they are often less active in organizations that may be of assistance to them such as trade associations [43]. In this study, SMEs is categorized into micro, small, and medium enterprises based on their annual sales turnover as defined by SME Corporation (2014). Therefore, we hypothesized that:

H1: There is significant relationship between business profile and the adoption of sustainable manufacturing practices among food and beverage SMEs in Peninsular Malaysia.

\section{METHODOLOGY}

A survey was conducted to collect survey information on the adoption of sustainable manufacturing practices among SMEs food and beverages manufacturers in Peninsular Malaysia. A structured questionnaire was designed into six sections. The questionnaire was designed by using Likert Scale of 1 to 5 (1 represents strongly disagree and 5 as strongly agree) to measure SME's manufacturers benefit in adopting the sustainable manufacturing practices. Primary data was used to achieve the objectives of the study given that this is a quantitative study. It is one of the reliable methods which is also a survey method of data collection that can ensure data information is up to date and able to provide answer to the research questions and hypothesis. A survey is one of the common and established methods used for primary data collection [44].It allows the researchers to create information to answer all questions concerning the independent and dependent variables [45].

This study was carried out in Peninsular Malaysia as the proportion of food and beverages SMEs is higher in Peninsular Malaysia. Peninsular Malaysia consists of 11 states and 2 federal territories. All of the states are categorized into four regions, namely northern region (Perlis, Kedah, Pulau Pinang, Perak), east coast region (Kelantan, Terengganu, Pahang), central region (Selangor, Negeri Sembilan, federal territories of Kuala Lumpur and Putrajaya), and southern region (Melaka, Johor) The total number of SMEs established for the manufacturing sector is 47,698. The percentage share of SMEs in manufacturing sector in Malaysia for food and beverages is $17.4 \%$ accounting for 8300 firms. The total number of food and beverages SMEs in Peninsular Malaysia is 6910. Slovin's Formula was used to obtain the sample size for this study where $n$ denotes the sample size andis given by:

$n=\frac{N}{1+N(e)^{2}}$

whereN is the population size and e is the margin error which is 0.05 [46]. The sample size for this research was calculated and the result is 378 firms of sample size representing the total number of food and beverages SMEs of 6910. This study involved participation of 378 SME entrepreneurs in manufacturing sector focusing on food and beverages industries from all states in Peninsular Malaysia. The samples were selected from directory of SME Corporation Malaysia using random sampling method. A consecutive number from 1 to $\mathrm{N}$ (6910) was assigned for each of the SMEs. Random numbers from random number tables were obtained to select 378 samples 
from 6910 SMEs [47]. Questionnaires were distributed to 378 SMEs. Enumerators were assigned to each of state in the Peninsular Malaysia to assist with the data collection. 375 SMEs completed the questionnaires and 3 questionnaires were excluded because of the incomplete information.

The collected data were analysed using descriptive analysis and chi-square analysis. Descriptive analysis is one of the statistical methods where raw data is transformed into a simpler form to facilitate understanding and interpretation. Percentage, frequency distribution and average of the raw data can be pinpointed using this technique. It is also used to illustrate the basic characteristics of the data in a study. Descriptive analysis summarizes a given data set, which can represent the entire population or a sample. In this study, descriptive analysis was used to describe the business profile of the SME's food and beverages and socio demographic profile of respondent that participated in this study. Besides, the benefits of adopting the sustainable manufacturing practices was described using descriptive analysis. Meanwhile, chisquare analysis was carried out to identify the association of business profile of SME's food and beverages manufacturers and the adoption of sustainable manufacturing practices.

Chi-square $\left(\chi^{2}\right)$ is a non-parametric test of significance when the data is in the form of frequency counts occurring in two or more mutually exclusive categories [48]. This test is also used to determine whether the experimentally observed results are consistent with construct hypothesis. More specifically, Karl Pearson (1857-1936) was the first person who developed the chi-square test and the logic of hypothesis testing. The two main purposes of chi-square analysis are to test the hypothesis of no association between two or more variables and to test how likely the observed distribution of data fits with the expected distribution, also known as the goodnessof-fit test. It is used to analysecategorical data such as male or female but not for parametric or continuous data such as weight measure in $\mathrm{kg}$. Furthermore, the chi-square test can be used for any variable including the group (independent) and the test variable (dependent) that are either nominal, dichotomous, ordinal, or interval scale. The chi-square is calculated using the followingformula:

$x^{2}=\sum_{\mathrm{i}=1}^{n} \frac{\left(O_{\mathrm{i}}-E_{\mathrm{i}}\right)^{2}}{E_{\mathrm{i}}}$

Where,

$\mathrm{O}=$ observed frequency

$\mathrm{E}=$ expected frequency

For the purpose of this study, chi-square analysis was employed to test if there is significant association between adoption of sustainable manufacturing practices among SMEs food and beverages industries in manufacturing sector and SMEs business profile.

$\mathbf{H}_{\mathbf{0}}=$ There is no significant association between business profile and adoption of sustainable practices among food and beverages SMEs

$\mathbf{H}_{\mathbf{1}}=$ There is significant association between business profile and adoption of sustainable practices among food and beverages SMEs 


\section{RESULTS AND DISCUSSION}

\subsection{Descriptive Analysis}

The business profiles of the food and beverages SMEs in the present study include location based on region, years of establishment, and annual sales turnover. Table 1demonstrates that majority of the food and beverage SMEs that responded in this study were located in Central Region (Selangor and Wilayah Persekutuan) which accounted for 32.6\%, followed by Northern Region (Perlis, Kedah, Perak, Penang) which accounted for 31.2\%. Only $14.4 \%$ of the total respondents were SMEs from East Coast Region (Kelantan, Pahang, and Terengganu). Based on the [1], more than $60 \%$ of SME's were mainly concentrated in the top five states, namely Selangor, Kuala Lumpur, Johor, Perak and Pulau Pinang.Table 1 also shows that the establishment of most of the food and beverages SMEs responded in this study comprised of 1 to 10 years $(61.9 \%)$, followed by 11 to 21 years $(26.1 \%)$ and 21 to 30 years $(5.3 \%)$. The remaining $4.5 \%$ and $2.1 \%$ comprised of SMEs established from 31 to 40 years and 41 to 50 years, respectively. According to[1],small enterprises with annual sales turnover between RM300,000 and RM15 million arecategorized as small enterprises. Medium enterprises are identified by annual sales turnover between RM15 million to RM50 million whereas micro enterprises comprise of annual sales turnover less than RM300 000. Therefore, based on the given definition of enterprise, there were $66.7 \%$ (250) of small enterprises SMEs, 27.2\% (102) were micro enterprises and $6.1 \%$ (23) of the SMEs were medium enterprises.

Table 1: Business Profile of SME's Food and Beverages Manufacturers

\begin{tabular}{|l|l|l|}
\hline Profile & Frequency (n) & \multicolumn{2}{l|}{ Percentage (\%) } \\
\hline \multicolumn{2}{|l|}{ Location based on region } & \multicolumn{2}{l|}{} \\
\hline East Coast Region & 20 & 5.3 \\
\hline Kelantan & 15 & 4.0 \\
\hline Pahang & 19 & 5.1 \\
\hline Terengganu & & 10.7 \\
\hline Northern Region & 40 & 1.6 \\
\hline Kedah & 6 & 7.7 \\
\hline Perlis & 29 & 11.2 \\
\hline Penang & 42 & \\
\hline Perak & & \\
\hline Central Region & & \\
\hline
\end{tabular}


International Journal of Agriculture, Environment and Bioresearch

Vol. 4, No. 05; 2019

ISSN: $2456-8643$

\begin{tabular}{|l|l|l|}
\hline Selangor & 91 & 24.3 \\
\hline Wilayah Persekutuan & 31 & 8.3 \\
\hline Southern Region & 16 & 4.3 \\
\hline Negeri Sembilan & 12 & 3.2 \\
\hline Melaka & 54 & 14.4 \\
\hline Johor & \multicolumn{2}{|l|}{} \\
\hline Years of Establishment & 232 & 61.9 \\
\hline $1-10$ & 98 & 26.1 \\
\hline $11-21$ & 20 & 5.3 \\
\hline $21-30$ & 17 & 4.5 \\
\hline $31-40$ & 8 & 2.1 \\
\hline $41-50$ & & \\
\hline Annual Sales Turnover (RM) & 102 & 27.2 \\
\hline RM300000 & 250 & 66.7 \\
\hline RM300000-RM15 Millions & 23 & 6.1 \\
\hline RM15 Millions-RM50 Millions & & \\
\hline
\end{tabular}

Table 2 shows that most of the respondents consisted of male with $54.7 \%$ (205), whereasfemale accounted for $45.3 \%$ (170). Majority of the respondents comprised of age between 28-37 years old with $37.9 \%$ (142), followed by age group of 38-47 years old with $27.5 \%$ (103), age group between $48-57$ years old with $19.5 \%$ (73),18-27 years old with $11.2 \%$ (42) and 57 years old above accounted for $4.0 \%$ (15). In terms of level of education, $41.6 \%$ (156) of the respondents possessedBachelor's degree, $24.0 \%$ (90) have completed Diploma and 16.3\% (61) attained secondary school certificate. Master's Degree and Doctorate holders accounted for $11.5 \%$ (43) and $6.7 \%$ (25) of the total respondents, respectively. Table 2 also showsthat majority of the respondents held Chief Executive Officer and general manager as the position in a company which accounted for $26.4 \%$ (99), followed by marketing manager with $19.2 \%$ (72), supervisors with 5.9\% (22), Chief Information Officer with 5.3\% (20), and Chief Operating Officer with $4.5 \%$ (17). Respondents who held the position as inventory and logistic manager accounted for $3.7 \%$ (14) and about $3.2 \%$ (12) held the position as plant manager. The result also showed that $2.9 \%$ (11) consisted as others (supporting staff), $1.3 \%$ (5) as operation manager and only $1.1 \%$ (4) as purchasing and procurement manager. With regards to year(s) of working experience, 
$48.3 \%$ (181) of the respondents in the present study have accumulated 1-10 years of working experience, $25.9 \%$ (97) with 11-20 years of working experience, and $16.0 \%$ (60) with 21-30 years of working experience. Respondents who have accumulated 31-40 years of working experience only accounted for $9.1 \%$ (34) and about $0.8 \%$ (3) have more than 40 years of working experience. Finally, in terms of year(s) of employment at the current company, Table 2 shows that $78.4 \%$ (294) of the respondents have been working for 1-10 years, while $17.1 \%$ (64) of the respondent have been employed between 11-20 years. 2.9\% (11) of the respondents have 21-30 years of employment at the current company and respondents who have between 31-40 years of employment were the least with $1.6 \%$ (6).

Table 2: Respondent's Socio Demographic Profile

\begin{tabular}{|c|c|c|}
\hline Profile & Frequency (n) & Percentage (\%) \\
\hline \multicolumn{3}{|l|}{ Gender } \\
\hline Female & 170 & 45.3 \\
\hline Male & 205 & 54.7 \\
\hline \multicolumn{3}{|l|}{ Level of Education } \\
\hline SPM/STPM & 61 & 16.3 \\
\hline Diploma & 90 & 24.0 \\
\hline Bachelor Degree & 156 & 41.6 \\
\hline Master Degree & 43 & 11.5 \\
\hline Doctorate & 25 & 6.7 \\
\hline \multicolumn{3}{|l|}{$\underline{\text { Age }}$} \\
\hline 18 to 27 & 42 & 11.2 \\
\hline 28 to 37 & 142 & 37.9 \\
\hline 38 to 47 & 103 & 27.5 \\
\hline 48 to 57 & 73 & 19.5 \\
\hline$>57$ & 15 & 4.0 \\
\hline \multicolumn{3}{|l|}{ Position in the Company } \\
\hline $\begin{array}{l}\text { Chief Executive } \text { Officer } \\
(\mathrm{CEO})\end{array}$ & 99 & 26.4 \\
\hline
\end{tabular}


International Journal of Agriculture, Environment and Bioresearch

Vol. 4, No. 05; 2019

ISSN: $2456-8643$

\begin{tabular}{|c|c|c|}
\hline $\begin{array}{|lll|}\begin{array}{l}\text { Chief } \\
(\mathrm{COO})\end{array} & \text { Operating } & \text { Officer } \\
\end{array}$ & 17 & 4.5 \\
\hline $\begin{array}{l}\text { Chief Information Officer } \\
\text { (CIO) }\end{array}$ & 20 & 5.3 \\
\hline General Manager & 99 & 26.4 \\
\hline Plant Manager & 12 & 3.2 \\
\hline \begin{tabular}{|l} 
Inventory and Logistic \\
Manager
\end{tabular} & 14 & 3.7 \\
\hline Marketing Manager & 72 & 19.2 \\
\hline $\begin{array}{l}\text { Purchasing and Procurement } \\
\text { Manager }\end{array}$ & 4 & 1.1 \\
\hline Operation Manager & 5 & 1.3 \\
\hline Supervisor & 22 & 5.9 \\
\hline Others & 11 & 2.9 \\
\hline \multicolumn{3}{|c|}{ Year(s) of Working Experience } \\
\hline 1 to 10 & 181 & 48.3 \\
\hline 11 to 20 & 97 & 25.9 \\
\hline 21 to 30 & 60 & 16.0 \\
\hline 31 to 41 & 34 & 9.1 \\
\hline$>40$ & 3 & 0.8 \\
\hline \multicolumn{3}{|l|}{ Year(s) of Employment } \\
\hline 1 to 10 & 294 & 78.4 \\
\hline 11 to 20 & 64 & 17.1 \\
\hline 21 to 30 & 11 & 2.9 \\
\hline 31 to 40 & 6 & 1.6 \\
\hline
\end{tabular}

Table 3 demonstrates that $46.8 \%$ strongly agreed that the adoption of sustainable manufacturing practices can improve the brand image, followed by $43.5 \%$ who agreed with the statement. 
$46.5 \%$ and $42.5 \%$ of the respondents agreed and strongly agreed, respectively for the statement of reduce overall business costs. $44.2 \%$ of the respondents strongly agreed that the adoption of sustainable manufacturing practices can increase the profit of the firm, followed by $42.5 \%$ who agreed. In terms of increase the efficiency of overall supply chain, $45.5 \%$ strongly agreed with the statement, followed by $41.2 \%$ who strongly agreed. The overall mean score for the study was 4.21 , where a mean score above 4.0 indicates that the respondents had a strong agreement with a statement.

Table 3: Benefits of Adopting the Sustainable Manufacturing Practices

\begin{tabular}{|c|c|c|c|c|c|c|}
\hline Item & $\mathbf{1}$ & 2 & 3 & 4 & 5 & Mean \\
\hline & $\begin{array}{l}\text { Strongly } \\
\text { disagree }\end{array}$ & Disagree & $\begin{array}{l}\text { Neither } \\
\text { agree } \\
\text { nor } \\
\text { disagree }\end{array}$ & Agree & $\begin{array}{l}\text { Strongly } \\
\text { agree }\end{array}$ & \\
\hline 1. Improve brand image & 0 & $\begin{array}{l}9.6 \% \\
(29)\end{array}$ & 0 & $\begin{array}{l}43.5 \% \\
(131)\end{array}$ & $\begin{array}{l}46.8 \% \\
(141)\end{array}$ & 4.37 \\
\hline $\begin{array}{lrr}2 . & \text { Reduce } & \text { overall } \\
\text { business costs } & \end{array}$ & 0 & $\begin{array}{l}11.0 \% \\
(33)\end{array}$ & 0 & $\begin{array}{l}46.5 \% \\
(140)\end{array}$ & $\begin{array}{l}42.5 \% \\
(128)\end{array}$ & 4.32 \\
\hline 3. Increase profit & 0 & $0.7 \%(2)$ & $\begin{array}{l}12.6 \% \\
(38)\end{array}$ & $\begin{array}{l}42.5 \% \\
(128)\end{array}$ & $\begin{array}{l}44.2 \% \\
(133)\end{array}$ & 4.30 \\
\hline $\begin{array}{l}\text { 4. Increase the efficiency } \\
\text { of overall supply chain }\end{array}$ & 0 & $0.7 \%(2)$ & $\begin{array}{l}12.6 \% \\
(38)\end{array}$ & $\begin{array}{l}45.5 \% \\
(137)\end{array}$ & $\begin{array}{l}41.2 \% \\
(124)\end{array}$ & 4.27 \\
\hline 5. Gained new customers & $0.3 \%(1)$ & 0 & $\begin{array}{l}8.3 \% \\
(25)\end{array}$ & $\begin{array}{l}57.5 \% \\
(173)\end{array}$ & $\begin{array}{l}33.9 \% \\
(102)\end{array}$ & 4.25 \\
\hline $\begin{array}{l}\text { 6. Enhance } \text { Customer } \\
\text { Service Relationship } \\
\text { (CSR) }\end{array}$ & 0 & $1.0 \%(3)$ & $\begin{array}{l}13.3 \% \\
(40)\end{array}$ & $\begin{array}{l}45.2 \% \\
(136)\end{array}$ & $\begin{array}{l}40.5 \% \\
(122)\end{array}$ & 4.25 \\
\hline $\begin{array}{l}\text { 7. Differentiate from } \\
\text { competitors }\end{array}$ & 0 & $0.7 \%(2)$ & $15 \%(45)$ & $\begin{array}{l}47.5 \% \\
(143)\end{array}$ & $\begin{array}{l}36.9 \% \\
(111)\end{array}$ & 4.21 \\
\hline $\begin{array}{l}\text { 8. Reduce environmental } \\
\text { impacts }\end{array}$ & $0.7 \%(2)$ & 0 & $\begin{array}{l}16.3 \% \\
(49)\end{array}$ & $\begin{array}{l}54.2 \% \\
(1630\end{array}$ & $\begin{array}{l}28.9 \% \\
(87)\end{array}$ & 4.11 \\
\hline $\begin{array}{l}\text { 9. Reduce waste and } \\
\text { improved disposal }\end{array}$ & 0 & $1.0 \%(3)$ & $\begin{array}{l}17.3 \% \\
(52)\end{array}$ & $\begin{array}{l}52.5 \% \\
(158)\end{array}$ & $\begin{array}{l}29.2 \% \\
(88)\end{array}$ & 4.10 \\
\hline 10. Increase the use of & 0 & $0.7 \%(2)$ & $12.6 \%$ & $45.5 \%$ & $41.2 \%$ & 4.08 \\
\hline
\end{tabular}




\begin{tabular}{|c|c|c|c|c|c|c|}
\hline recyclable or reusable. & & & $(38)$ & (137) & $(124)$ & \\
\hline $\begin{array}{l}\text { 11. Reduce carbon } \\
\text { dioxide emission }\end{array}$ & $0.7 \%(2)$ & $0.7 \%(2)$ & $\begin{array}{l}18.9 \% \\
(57)\end{array}$ & $\begin{array}{l}52.8 \% \\
(159)\end{array}$ & $\begin{array}{l}26.9 \% \\
(81)\end{array}$ & 4.05 \\
\hline Overall Mean Score & & & & & & 4.21 \\
\hline
\end{tabular}

\subsection{Chi-Square Analysis}

Chi-square analysis was used to measure the association between the adoption of sustainable practices and business profile of the SMEs. The following hypotheses were evaluated using the above analysis

$\mathrm{H}_{0}$ : There is no significant association between business profile and adoption of sustainable manufacturing practices among food and beverage SMEs.

$\mathrm{H}_{1}$ : There is significant association between business profile and adoption of sustainable manufacturing practices among food and beverage SMEs.

Table 4 shows the analysis of crosstab of business profile of SMEs and adoption of sustainable manufacturing practices. The crosstab analysis was applied for all the business profile of SMEs. However, according to the Pearson Chi-Square value, only variable of region is significant with the adoption of sustainable practices. The different level of adoption of sustainability practices was clustered as low versus high adopters based on the total number of practices adopted [49]. The relationship between location of the SMEs based on region and the adoption of sustainable practices are shown in Table 4. SMEs located in the central region were the majority group that adopt high adoption of the sustainable practices accounting for $34.4 \%$, followed by northern region which accounted for $30.0 \%$. However, the SMEs located in the East coast region only composed $10.8 \%$ of the total SMEs who practiced high adoption of sustainable manufacturing practices.

Table 4: Crosstab Table Analysis

\begin{tabular}{|l|l|l|l|l|l|}
\hline \multirow{2}{*}{ Variable } & \multicolumn{2}{|l|}{ Low Adoption } & \multicolumn{2}{l|}{ High Adoption } & $\begin{array}{l}\text { Pearson } \\
\text { Chi-Square }\end{array}$ \\
\cline { 2 - 6 } & $\begin{array}{l}\text { Frequency } \\
(\mathbf{n})\end{array}$ & $\begin{array}{l}\text { Percentage } \\
(\boldsymbol{\%})\end{array}$ & $\begin{array}{l}\text { Frequency } \\
(\mathbf{n})\end{array}$ & $\begin{array}{l}\text { Percentage } \\
(\boldsymbol{\%})\end{array}$ & \\
\hline a) Year of Establishment & 29 & 56.9 & 137 & 54.8 & 0.808 \\
\hline $1-10$ & 16 & 31.4 & 75 & 24.9 & 0.808 \\
\hline $11-20$ & & &
\end{tabular}


Vol. 4, No. 05; 2019

ISSN: $2456-8643$

\begin{tabular}{|c|c|c|c|c|c|}
\hline $21-30$ & 4 & 7.8 & 16 & 5.3 & 0.808 \\
\hline $31-40$ & 1 & 2.0 & 15 & 4.9 & 0.808 \\
\hline $41-50$ & 1 & 2.0 & 8 & 2.7 & 0.808 \\
\hline Total & 51 & $100 \%$ & 250 & $100 \%$ & \\
\hline Percentage (\%) & $16.9 \%$ & & $83.1 \%$ & & \\
\hline \multicolumn{6}{|l|}{ b) Region } \\
\hline $\begin{array}{ll}\text { East } & \text { coast } \\
\text { region } & \end{array}$ & 12 & 23.5 & 27 & 10.8 & 0.005 \\
\hline Northern region & 22 & 43.1 & 75 & 30.0 & 0.005 \\
\hline Central region & 9 & 17.6 & 86 & 34.4 & 0.005 \\
\hline Southern region & 8 & 15.7 & 62 & 24.8 & 0.005 \\
\hline Total & 51 & $100 \%$ & 250 & $100 \%$ & \\
\hline Percentage $\%$ & $16.9 \%$ & & 83.1 & & \\
\hline \multicolumn{6}{|c|}{ c) Annual sales turnover } \\
\hline$<300000$ & 12 & 23.5 & 52 & 20.8 & 0.268 \\
\hline $\begin{array}{l}300000-15 \\
\text { million }\end{array}$ & 38 & 74.5 & 177 & 70.8 & 0.268 \\
\hline $\begin{array}{l}15 \text { million-50 } \\
\text { million }\end{array}$ & 1 & 2.0 & 21 & 8.4 & 0.268 \\
\hline Total & 51 & $100 \%$ & 250 & $100 \%$ & \\
\hline Percentage $\%$ & $16.0 \%$ & & $83.1 \%$ & & \\
\hline
\end{tabular}

Table 5 shows that out of the three variables on business profile characteristics, only one variable is statistically significant associated with the adoption of sustainable practices among food and beverage SMEs at $1 \%$ significance level $(\alpha=0.01)$. The variableregion $(\mathrm{p}=0.005)$ is significant at $1 \%$ level of significance. Two variables, namely years of establishment and annual sales turnover showed no statistically significant association with the adoption of sustainable practices. Thepresent finding corresponded with [49]where the age of a firm and the annual sales turnover were not associated with the adoption of sustainable practices. On the other hand, [38]reported that the important driver to good environmental management practices is the size of the firm, 
Vol. 4, No. 05; 2019

ISSN: $2456-8643$

including human resources. Hence, this implies that the adoption of sustainable practices among food and beverage SMEs significantly depended on region.

Table 5: Association between business profile and adoption of sustainable manufacturing practices among SME's food and beverages manufacturers.

\begin{tabular}{|l|l|l|l|l|}
\hline Variable & $\mathbf{X}^{\mathbf{2}}$ & d.f & Significant & Decision \\
\hline Years of Establishment & 1.604 & 2 & 0.808 & Fail to reject $\mathrm{H}_{0}$ \\
\hline Region & $\mathbf{1 2 . 8 4 6}$ & $\mathbf{3}$ & $\mathbf{0 . 0 0 5}$ & Reject $\mathbf{H}_{\mathbf{0}}$ \\
\hline Annual sales Turnover & 2.633 & 2 & 0.268 & Fail to reject $\mathrm{H}_{0}$ \\
\hline
\end{tabular}

Note:Significant at $1 \%$ level of significance

\section{CONCLUSION}

Majority of the food and beverage SME's that responded in this study were located in Central Region (Selangor and Wilayah Persekutuan), which accounted for 32.6\% followed by Northern Region (Perlis, Kedah, Perak, Penang), which accounted for $31.2 \%$. The present findings revealed that about $66.7 \%$ (250) of the SME's had annual sales turnover between RM300, 000 to less than RM15 million. The rest, around 27.2\% (102) of the SME's had less than RM300 000 of annual sales turnover. The mean ranking analysis was used to evaluate the statements of benefit in adopting the sustainable practices in the firm's daily operation. The overall mean score for the study is 4.21. Chi-square analysis was carried out to investigate the association between business profile of food and beverage SME's and the adoption of sustainable practices. The results showed that adoption of sustainable practices has positive significant association with region of SMEs. There are numbers of previous studies on sustainable practices carried out in other countries. However, the study on adoption of sustainable practices focusing on food and beverage industries in Malaysia related to environmental degradation caused by the daily operation is limited. This might due to lack of awareness on the environmental degradation caused by their firm. The rate of environmental degradation caused by the SMEs could be higher when compared to the large firms. However, most of the previous study only focused on the environmental degradation caused by the manufacturing activities of the large firms and the adoption of sustainable practices in the large firms. These results in limited statistics, facts and figures on adoption of sustainable practices among SMEs, specifically in food and beverage industries in Malaysia. In addition, the study was completed within three months of time frame and only covered Peninsular Malaysia areas., Therefore, this study might be lacking in terms of sample size and methods selected for analysis. Since the present study is only conducted in Peninsular Malaysia, it is recommended that future research should expand and include the states of Sabah and Sarawak. Granted that the adoption of sustainable practices among SMEs varies according to region, the inclusion of both states in the Borneo could provide greater sample size and therefore, more reliable studies. 
Vol. 4, No. 05; 2019

ISSN: $2456-8643$

\section{REFERENCES}

[1] NSDC (2017/18), SME Annual Report Malaysia, National SME Development Council. Retrieved from ww.smecowrp.gov.my/images/SMEAR/SMEAR2017/ENG/FULL.pdf

[2] Malaysian Industrial Development Authority. (2014). Food Industry in Malaysia. Retrieved from www.mida.gov.my/home/33/pages.

[3] Malaysian Industrial Development Authority. (2018). Food Industry in Malaysia. Retrieved from www.mida.gov.my/home/33/pages

[4] Nik Wan, N. Z., Asat, S. H., \& Zain, M. M. (2017). Environmental Reporting Practice by SMEs in Malaysia. In Global Business and Economics Research Journal, 383-387.

[5] Condon, L. (2004). Sustainability and small to medium sized enterprises-How to engage them. Australian Journal of Environmental Education, 20(1), 57-67.

[6] Feil, A. A., de Quevedo, D. M., \& Schreiber, D. (2015). Selection and identification of the indicators for quickly measuring sustainability in micro and small furniture industries. Sustainable Production and Consumption, 3(June), 34-44. https://doi.org/10.1016/j.spc.2015.08.006

[7] Papargyropoulou, E., Wright, N., Lozano, R., Steinberger, J., Padfield, R., \& Ujang, Z. (2016). Conceptual framework for the study of food waste generation and prevention in the hospitality sector. Waste Management, 49: 326-336. https://doi.org/10.1016/j.wasman.2016.01.017

[8] Hussin, H. (2015). Green Logistic Practices in Malaysia Food-Based Manufacturing Industry, (Master's Thesis Universiti Putra Malaysia). Retrieved from http://psasir.upm.edu.my/id/eprint/56976/1/FP\%202015\%204RR.pdf

[9] Papargyropoulou, E., Lozano, R., K. Steinberger, J., Wright, N., \& Ujang, Z. bin. (2014). The food waste hierarchy as a framework for the. Journal of Cleaner Production, 76(0): 106-115. https://doi.org/10.1016/j.jclepro.2014.04.020.

[10] Searchinger, T., Hanson, C., Ranganathan, J., Lipinski, B., Waite, R., Winterbottom, R., Dinshaw, A., \& Heimlich, R. (2013). Creating a Sustainable Food Future: Interim Findings. A menu of solutions to sustainably feed more than 9 billion people by 2050. World Resources Institute (WRI), Washington, DC, 2013. Retrieved from the World Research Institute website: https://www.wri.org/sites/default/files/wri13_report_4c_wrr_online.pdf

[11] Padfield, R., Papargyropoulou, E., \& Preece, C. (2012). A preliminary assessment of greenhouse gas emission trends in the production and consumption of food in Malaysia. International Journal Technology, 3:55-66.

[12] Garnett, T., \& Garnett, T. (2008). Cooking up a Storm: Food, greenhouse gas emissions and our changing climate. International Journal of Climate Change Strategies and Management, 1(2): 211-217. https://doi.org/10.1108/ijccsm.2009.41401bae.006 [13] experiences. Sheffield: Greenleaf.

Hillary, R. (Ed.). (2000). ISO 14001: Case studies and practical

[14] The Star.( 2018,October 15). Malaysian throwing away food at alarming rate.

[15] Latip, M., Sharkawi, I., Sharifuddin, J., \& Mohamed, Z. (2018). Investigating Owner-Manager's Intention to Adopt Environmental Management Practices among Food Processing SMEs in Malaysia. International Journal of Entrepreneurship and 
Management Practices, 1 (3), 01-11.

[16] Anis, F. M. \& Nurul, F. H. (2012). The development of sustainable manufacturing practices and sustainable performance in Malaysian automotive industry. Journal of Economics and Sustainable Development, 3(7): 130-138.

[17] Seidel, R. H. A., Shahbazpour, M., \& Seidel, M. C. (2007). Establishing sustainable manufacturing practices in SMEs. Proceedings of the International Conference on Sustainability Engineering and Science, Talking and Walking Sustainability. Auckland.

[18] Abdul Rashid, S. H., Sakundarini, N., Ariffin, R., \& Ramayah, T. (2017). Drivers for the adoption of sustainable manufacturing practices: A Malaysia perspective. International Journal of Precision Engineering and Marketing, 18(11),1619-1631.

[19] U.S. Department of Commerce: International Trade Administration (2009). Sustainable Manufacturing Initiative. Retrieved from United States Department of Commerce: International Trade Administration: http://www.trade.gov/competitiveness/sustainablemanufacturing/

[20] Schoenherr, T., \& Talluri, S. (2012). Environmental Sustainability Initiatives: A Comparative Analysis of Plant Efficiencies in Europe and the U.S. Science. IEEE Transactions on Engineering Management, 35(1), 87-108.

[21] Carley, S., Jasinowski, J., Glassley, G., Strahan, P., Attari, S. \& Shackelford, S. (2014). Success Paths to Sustainable Manufacturing, (October), 5-29.

[22] Miller, G., Pawloski, J., \& Stanridge, C. (2010). A Case study of lean, sustainable manufacturing. Journal of Industrial Engineering and Management, 11-32.

[23] Tu, Q., Vonderembse, M.A., Ragu-Nathan, T.S., Sharkey, T. W. (2006). Absorptive capacity: enhancing the assimilation of time-based manufacturing practices. Journal of Operations Management, 24(5), 692-710.

[24] Lopes, R. B., Freitas, F., \& Sousa, I. (2015). Application of lean manufacturing tools in the food and beverage industries. Journal of Technology Management and Innovation, 10(3): 120-130.

[25] Rusinko, C. A. (2007). Green manufacturing: an evaluation of environmentally sustainable manufacturing practices and their impact on competitive outcomes. IEEE Transactions on Engineering Management, 54(3), 445-454.

[26] Morath, C., \& Doluschitz, R. (2009). 3 Current situation regarding Total Quality Management applications in the food industry. APSTRACT: Applied Study in Agribusiness and Commerce, 4(3), 83-87.

[27] Collins, E., Roper, J., \& Lawrence, S. (2009). Sustainability practices: Trends in New Zealand businesses. Business Strategy and the Environment, 18: 1-16.

[28] Littig, B., \&Grießler, E. (2005). Social sustainability: A catchword between political

pragmatism and social theory. International Journal of Sustainable Development, 8(2): 65-79.

[29] Lankoski, L. (2008). Corporate responsibility activities and economic performance: a theory of why and how they are connected. 17, 536-547. http://dx.doi.org/10.1002/bse.582. Business Strategy and the Environment, 17, 536-547. 
its

definitions: A content-analysis based literature review. Journal of Cleaner Naffziger, D. W., Almed, N., \& Montagno, R. V. (2003). Perceptions of environmental consciousness in US small businesses: an empirical study. SAM Advanced Management Journal, 68(2): 23-32. https://doi.org/10.1108/17561391111144546

[31] Bourlakis, M., Maglaras, G., Aktas, E., Gallear, D., \& Fotopoulos, C. (2014). Firm size and sustainable performance in food supply chains: Insights from Greek SMEs. International Journal of Production Economics, 152: 112-130. https://doi.org/10.1016/j.ijpe.2013.12.029

[32] Ilbery, B., \& Maye, D. (2005). Food supply chains and sustainability: Evidence from specialist food producers in the Scottish/English borders. Land Use Policy, 22(4): 331-344. https://doi.org/10.1016/j.landusepol.2004.06.002

[33] Lee, S. Y., \&Klassen, R. D. (2008). Drivers and enablers that foster environmental management capabilities in small and medium sized suppliers in supply chains. Production and Operations Management, 17(6): 573-586. https://doi.org/10.3401/poms.1080.0063

[34] Pool, A., Wijngaard, J., \& Van Der Zee, D. J. (2011). Lean planning in the semiprocess industry, a case study. International Journal of Production Economics, 131(1): 194-203. https://doi.org/10.1016/j.jpe.2010.04.040

[35] Jenkins, H. (2004). Corporate social responsibility: Engaging SMEs in the debate: Initial research findings. Report by: The ESRC Centre for Business Relationships, Accountability, Sustainability and Society. Retrieved from https://pdfs.semanticscholar.org/7de0/2cd7441d5a31114109bcbe81938d9c84be0c.pdf

[36] Lekas, D. (2006). Nanotechnology startup concerns, information needs, and opportunities to proactively address environmental, health and social issues: Focus on firms in Connecticut and New York. Retrieved from www.nanotechproject.org/file_download/87

[37] McKeiver, C. \& Gadenne, D. (2005). Environmental management systems in small and medium businesses. International Small Business Journal, 23(5), 513-537.

[38] Moorthy, M. K., Yacob, P., Chelliah, M. K., \& Arokiasamy, L. (2012). Drivers for Malaysian SMEs to Go Green. International Journal of Academic Research in Business and Social Science, 2(9), 74-86.

[39] Upton, N., Teal, E.J., \& Felan, J.T. (2001). Strategic business planning practices of fast growing family firms. 39(1). Journal of Small Business Management, 39(1): 6072.

[40] Storey, D. J. (2004). Exploring the Link, amongst Small firms between management Training and Firm Performance: A comparison Between UK and Other OECD Countries. The International Journal of Human Resource Management, 15: 112130.

[41] Rajendran, D., \& Barrett, R. (2003). Managing Environmental Risk in Small Business: An Agenda for Research (pp. 1-10).

[42] D'Souza, C \& Peretiatko, R. (2002). The nexus between industrialization and environment. Environment Management and Health, 13(1), 80-97. 
[43] Rothenberg, S. \& Becker, M. (2004). Technical assistance and the diffusion of environmental technologies in the printing industry. The Case of SMEs. Business and Society, 43(4), 366-397.

[44] Hox, J. J., \& Boeije, H. R. (2005). Data collection: Primary vs. secondary. Encylopedia of Social Measurement, 1: 593-599. https://doi.org/10.1016/B0-12-3693985/00041-4

[45] Hair, J.F., Bush, R.P., \& Ortinau, D.J. (2006). Marketing Research: Within a changing information environment. Boston, MA: McGraw-Hill//rwin.

[46] Wen, F. J., \& Chung, P. S. (2011). Design of a high-efficiency seven-port beam splitter using a dual duty cycle grating structure. Applied Optics, 50(19), 3187. https://doi.org/10.1364/AO.50.003187

[47] Salazar, L.F., Crosby, R.A., \& DiClemente, R.J. (2015). Research Method in Health Promotion. ( ${ }^{\text {nd }}$ ed). John Wiley \& Sons.

[48] Kothari, C. R. (2007). Quantitative techniques. New Delhi: UBS Publishers LTD.

[49] Russell, S. N., \& Millar, H. H. (2014). Exploring the Relationships among Sustainable Manufacturing Practices, Business Performance and Competitive Advantage: Perspectives from a Developing Economy. Journal of Management and Sustainability, 4(3), 37-53. https://doi.org/10.5539/jms.v4n3p37 